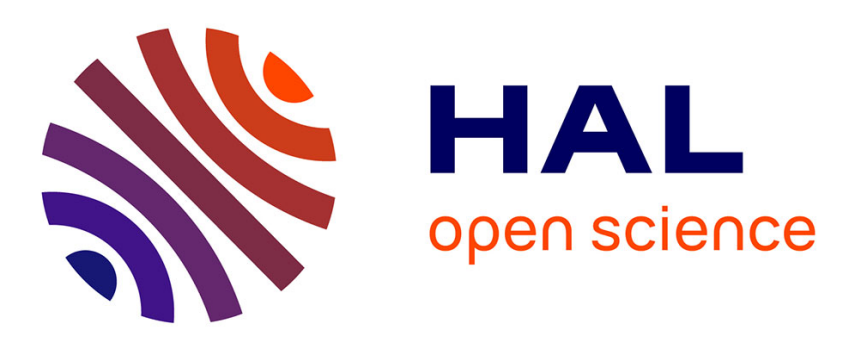

\title{
Determination of sex and scrapie resistance genotype in preimplantation ovine embryos
}

Florence Guignot, Gérard Baril, Francis Dupont, Yves Cognié, José Folch, José Luis Alabart, Naty Poulin, Jean-François Beckers, Bertrand Bed'Hom, Jean-Marc Babilliot, et al.

\section{To cite this version:}

Florence Guignot, Gérard Baril, Francis Dupont, Yves Cognié, José Folch, et al.. Determination of sex and scrapie resistance genotype in preimplantation ovine embryos. Molecular Reproduction and Development, 2009, 76 (2), pp.183-190. 10.1002/mrd.20940 . hal-02360345

\section{HAL Id: hal-02360345 \\ https://hal.science/hal-02360345}

Submitted on 30 May 2020

HAL is a multi-disciplinary open access archive for the deposit and dissemination of scientific research documents, whether they are published or not. The documents may come from teaching and research institutions in France or abroad, or from public or private research centers.
L'archive ouverte pluridisciplinaire $\mathbf{H A L}$, est destinée au dépôt et à la diffusion de documents scientifiques de niveau recherche, publiés ou non, émanant des établissements d'enseignement et de recherche français ou étrangers, des laboratoires publics ou privés. 


\title{
Determination of Sex and Scrapie Resistance Genotype in Preimplantation Ovine Embryos
}

\author{
FLORENCE GUIGNOT, ${ }^{1 *}$ GERARD BARIL, ${ }^{1}$ FRANCIS DUPONT, ${ }^{1}$ YVES COGNIE, ${ }^{1}$ JOSE FOLCH, ${ }^{2}$ \\ JOSE LUIS ALABART, ${ }^{2}$ NATY POULIN, ${ }^{1}$ JEAN-FRANCOIS BECKERS,${ }^{3}$ BERTRAND BED'HOM, ${ }^{4}$ \\ JEAN-MARC BABILLIOT, ${ }^{5}$ AND PASCAL MERMILLOD ${ }^{1}$ \\ ${ }^{1}$ UMR INRA-CNRS-Université de Tours-Haras Nationaux, Physiologie de la Reproduction et des Comportements, \\ Nouzilly, France \\ ${ }^{2}$ Centro de Investigación y Tecnología Agroalimentaria (CITA), Zaragoza, Spain \\ ${ }^{3}$ Université de Liège, Faculté de Médecine Vétérinaire, Physiologie de la Reproduction, Liège, Belgium \\ ${ }^{4}$ INRA, AgroParisTech, UMR1236 Génétique et Diversité Animales, Jouy en Josas, France \\ ${ }^{5}$ LABOGENA, Unité Ovicap, Jouy en Josas, France
}

\begin{abstract}
The aim of this study was to test the accuracy of genotype diagnosis after pre-amplification of DNA extracted from biopsies obtained by microblade cutting of ovine embryos and to evaluate the viability of biopsied embryos after vitrification/warming and transfer to recipients. Sex and PrP genotypes were determined. Sex diagnosis was done by PCR amplification of ZFX/ZFY and SRY sequences after PEP-PCR while PrP genotype determination was performed after specific pre-amplification of specific target including codons 136, 154 and 171. Embryos were collected at Day 7 after oestrus. Blastocysts and expanded blastocysts were biopsied immediately after collection whereas compacted morulae were biopsied after $24 \mathrm{hr}$ of in vitro culture. Eighty-nine biopsied embryos were frozen by vitrification. Fresh and vitrified whole embryos were kept as control. DNA of biopsies was extracted and pre-amplified. Sex diagnosis was efficient for $96.6 \%$ of biopsies and $\operatorname{PrP}$ genotyping was determined in $95.8 \%$ of codons. After embryo transfer, no significant difference was observed in lambing rate between biopsied, vitrified control and fresh embryos (54.5\%, 60\% and $66.6 \%$, respectively). Embryo survival rate was not different between biopsied and whole vitrified embryos $(P=0.38)$. At birth, $96.7 \%$ of diagnosed sex and $95.4 \%$ of predetermined codons were correct. Lamb PrP profiles were in agreement with parental genotype. PEP-PCR coupled with sex diagnosis and nested PCR coupled with PrP genotype predetermination are very accurate techniques to genotype ovine embryo before transfer. These original results allow planning of selection of resistant genotype to scrapie and sex of offspring before transfer of cryopreserved embryo. Mol. Reprod. Dev. ( 2008 Wiley-Liss, Inc.
\end{abstract}

Key Words: biopsy; dpi; PrP genotyping; sex diagnosis; vitrification; transfer

\section{INTRODUCTION}

Scrapie is a fatal transmissible spongiform encephalopathy (TSE) in sheep and goats caused by prions, similar to bovine spongiform encephalopathy (BSE) in cattle, Creutzfeldt-Jacob disease (CJD) and kuru in humans, or chronic wasting disease (CDW) in wild ruminants. TSEs are characterized by the accumulation of an abnormal isoform (Protein Prion Scrapie, $\mathrm{PrP}^{\mathrm{Sc}}$ ) of the normal cellular prion protein (Protein Prion Cellular, $\operatorname{PrP}^{\mathrm{C}}$ ) in the central nervous system of affected animals, according to the prion hypothesis (Prusiner, 1982). This pathogenic conformer is insoluble, protease K resistant (Bolton et al., 1982) and had a higher content of $\beta$-sheet (43\%) as compared to the normal form of $\mathrm{PrP}^{\mathrm{C}}$ (3\%) (Pan et al., 1993). Sheep resistance and susceptibility to scrapie is largely under genetic control, particularly the prion protein $(\mathrm{PrP})$ gene (Dickinson, 1976; Hunter, 1997). Major polymorphisms of this gene are located at codons 136 (T, A, V), $154(\mathrm{R}, \mathrm{H})$ and 171 (R, $\mathrm{Q}, \mathrm{H}, \mathrm{K})$, but only some combinations were found: $\mathrm{ARQ}$, a probable ancestral allele, VRQ, AHQ, ARH, ARR, 4 frequently derived alleles, and rarely derived alleles TRQ and ARK. The ARR and AHQ haplotypes are mainly associated with resistance and VRQ with susceptibility (Hunter et al., 1996; Elsen et al., 1999; Diaz et al., 2005). Recently, new codons associated with scrapie resistance were detected (Goldmann et al., 2005). In several European breeds, selection of the ARR/ARR genotype has been implemented to improve resistance to scrapie, mainly due to possible links between animal diseases and human health. This selection was carried out by crossing parents of resistant genotype and only ARR/ARR rams were conserved. Little is known about transmission of scrapie between animals or flocks but maternal transmission to lambs is strongly suspected. The most likely pathway of scrapie transmission from ewes to lambs is an early

*Correspondence to: Florence Guignot, INRA, PRC, Domaine de l'Orfrasière, Nouzilly 37380, France. E-mail: guignot@tours.inra.fr

Received 19 February 2008; Accepted 24 April 2008

Published online in Wiley InterScience

(www.interscience.wiley.com).

DOI $10.1002 / \operatorname{mrd} .20940$ 
lateral post-natal event rather than in utero transmission (Andréoletti et al., 2002). Thus, embryo transfer procedures could circumvent vertical transmission even when the offspring are of a high-risk genotype (Wang et al., 2002).

The biopsy of early mammalian embryos is now commonly used for genotyping and assessment of certain inherited genetics disorders (for a review see Bredbacka, 2001; Georges, 2001). The challenge is to detect by marker assisted selection (MAS) genetic information linked to economic trait loci to implement in breeding program. In particular, sex predetermination of offspring allows sex ratio manipulation in domestic animals and has a major impact on animal breeding, decreasing the generation interval and the cost of the breeding process. Since the 1990s, polymerase chain reaction (PCR) was largely used to amplify a Y chromosome-specific sequence (SRY, sex-determining region $\mathrm{Y}$ ) either alone, or with an autosomal sequence for control (Peura et al., 1991; Bernardi and Delouis, 1996; Lopes et al., 2001; Manna et al., 2003; Mara et al., 2004). Genes common to $\mathrm{X}$ and $\mathrm{Y}$ chromosomes (ZFY/ZFX, zinc finger protein) can also be amplified by a single primer pair and after amplification, a specific restriction endonuclease is required to identify male and female (Aasen and Medrano, 1990; Bredbacka and Peippo, 1992; Bredbacka et al., 1995; Kochhar et al., 2000). The number of isolated cells affects the accuracy of PCR sex diagnosis. When fewer than five cells were analysed, the efficiency of sexing decreased (Lacaze et al., 1996, 2007). Accordingly, 8-10 blastomeres have been recommended for successful sexing of embryos in the field (Thibier and Nibart, 1995). A novel DNA amplification method, loopmediated isothermal amplification (LAMP), without thermal cycling and electrophoresis, was reported to sex embryos efficiently with only $3-5$ cells (Notomi et al., 2000; Hirayama et al., 2004).

When several genetic markers are to be analysed, sufficient DNA is required to obtain an accurate result. However, biopsy can be detrimental to embryo viability and should be minimized in order to avoid pregnancy failure after embryo transfer. Therefore, preliminary amplification of the genome from only a few cells is needed to obtain sufficient DNA for several genetic analyses without reducing embryo viability. A primer extension pre-amplification (PEP) was described by Zhang et al. (1992) for the amplification of the whole genome from a single cell using a random mixture of 15-base oligonucleotides as primers. Variable efficiency of this technique was reported in regard to the length of the PEP program, 30-100\% (Xu et al., 1993; Hochman et al., 1996; Sermon et al., 1996; Chrenek et al., 2001). Another approach was to preamplify by PCR a genomic fragment including all regions of interest (nested PCR) before the specific PCR amplification (Appa Rao and Totey, 1999; Lien et al., 1999; Virta et al., 2002; Peippo et al., 2007). All these pre-amplification techniques take time and the biopsied embryos must generally be stored by cryopreservation before transfer, waiting for result of genotyping diagnosis.
In the present study, sex diagnosis and PrP genotype predetermination were carried out on ovine embryo microblade biopsies. Sex diagnosis was done by PCR amplification of ZFY/ZFX and SRY sequences after primer extension pre-amplification (PEP-PCR), while PrP genotype determination was done after specific preamplification (nested PCR) of specific sequence including codons 136, 154 and 171. Accuracy of genotype diagnosis after DNA pre-amplification was tested and the viability of biopsied embryos was evaluated after vitrification/warming and embryo transfer.

\section{MATERIALS AND METHODS}

\section{Animals}

The oestrous cycles of Ile-de-France and Aragonesa ewes (donors and recipients) were synchronized by insertion of an intravaginal sponge containing $40 \mathrm{mg}$ FGA (Chronogest ${ }^{\circledR}$, Intervet, Angers, France) for 13 days (Day $0=$ sponge insertion). At sponge removal, the recipients received $500 \mathrm{IU}$ of eCG $\left(\right.$ Chronogest ${ }^{\circledR}$ ). Donors were superovulated with a total of $200 \mu \mathrm{g}$ pFSH (Mérial, Belgium) injected intramuscularly every $12 \mathrm{hr}$ in six decreasing doses $(50,50,30,30,20$ and $20 \mu \mathrm{g})$ during the last 3 days of progestagen treatment (Days 11-13). pFSH treatment was supplemented with 66 and $90 \mu \mathrm{g} \mathrm{LH}$ in the last two injections, respectively. Donors were mated with selected rams and/or inseminated in utero under endoscopic control with frozen/thawed semen from selected fertile rams $\left(200 \times 10^{6}\right.$ spermatozoa per female) $20-24 \mathrm{hr}$ after the onset of oestrus. The mating was chosen in order to obtain large variability of embryo PrP genotype.

\section{Embryo Collection}

Embryos were recovered surgically by laparotomy under general anesthesia (i.v. thiopental $10 \mathrm{mg} \mathrm{kg}^{-1}$, atropine sulphate $0.3 \mathrm{mg} \mathrm{kg}^{-1}$ and endotracheal intubation with isoflurane and oxygen) 7 days after the onset of estrus. Each uterine horn was flushed with $40 \mathrm{ml}$ of prewarmed PBS containing $0.2 \%$ bovine serum albumin (BSA) (Euroflush, IMV, l'Aigle-France). The embryos were immediately retrieved and placed in PBS containing $0.4 \%$ BSA (Embryo holding medium, IMV, l'AigleFrance) at +20 to $+25^{\circ} \mathrm{C}$. They were selected according to their quality (grades 1 and 2) and classified according to their stage of development. Blastocysts and expanded blastocysts were selected for biopsy (0 hr biopsy). Compacted morulae were in vitro cultured for $24 \mathrm{hr}$ in modified synthetic oviduct fluid (SOF; Holm et al., 1999 ) with $5 \%$ foetal calf serum (FCS) in $5 \% \mathrm{CO}_{2}, 5 \% \mathrm{O}_{2}$, $90 \% \mathrm{~N}_{2}$ atmosphere before biopsy at the blastocyst stage (24 hr biopsy). Whole blastocysts and expanded blastocysts were vitrified as controls at 0 and $24 \mathrm{hr}$. For fresh whole embryo transfer, only compacted morulae, blastocysts and expanded blastocysts were kept. After embryo collection, local antibiotic (Aluspray) was sprayed on the abdominal incision, and each donor received benzylpenicilline and dihydrostreptomycine for 3 days (i.m., $1 \mathrm{~g}$ per day). 


\section{Embryo Biopsy}

Prior to biopsy, each embryo was washed 3 times in a $30 \mu \mathrm{l}$ drop of PBS without BSA. The biopsy was carried out using an inverted microscope (CK-2; Olympus, 200×) and a Narishige micromanipulator with a metal microblade adapted as a cutting instrument. The microblade was positioned above the embryo, taking care to exclude the inner cell mass and include only the trophectoderm. A small piece composed of approximately $8-10$ cells of trophectoderm was cut with a single vertical movement of the microblade. After cutting, a microdrop of PBS with $0.4 \%$ BSA was added. Trophectoderm cells of the biopsy were detached from the piece of zona pellucida and were deposed in a sterile tube without medium and frozen at $-20^{\circ} \mathrm{C}$ until DNA extraction. The biopsied embryo was immediately vitrified, with or without zona pellucida. Between each embryo biopsy, the microblade was washed in water, then $70 \%$ ethanol, water again and finally PBS without BSA. This biopsy technique permitted the sectioning of 15-20 embryos per hour.

\section{Embryo Cryopreservation}

Biopsied embryos were individually loaded in each straw, while two whole embryos were loaded per straw for direct transfer. The vitrification method described by Mermillod et al. (1997) and modified by Guignot et al. (2006) was applied. Briefly, embryos were kept at room temperature for 5 min in PBS supplemented with $20 \%$ new-born calf serum (NBCS). They were then vitrified in three steps at room temperature as follows: $10 \%$ glycerol for $5 \mathrm{~min}, 10 \%$ glycerol and 20\% ethylene glycol (EG) for $5 \mathrm{~min}$, and finally 25\% glycerol, 25\% EG and $0.4 \mathrm{M}$ sucrose for 30 sec in PBS-NBCS. During the last step, embryos were quickly aspirated into the centre of a $0.25 \mathrm{ml}$ plastic straw (IVM, L'Aigle, France) within 20-30 $\mu \mathrm{l}$ of vitrification solution. Embryos were separated by two air bubbles from two surrounding segments of PBS-NBCS containing $0.8 \mathrm{M}$ galactose (about $90 \mu \mathrm{l}$ each). The straws were sealed and immediately plunged into liquid nitrogen.

\section{DNA Extraction}

DNA of biopsies was extracted at $35^{\circ} \mathrm{C}$ for 30 min with proteinase $\mathrm{K}$. The extraction mix $(20 \mu \mathrm{l})$ contained $2 \mu \mathrm{l}$ of $10 \times$ PCR buffer, $0.6 \mu \mathrm{l}$ of $10 \mu \mathrm{g} / \mu \mathrm{l}$ proteinase K (Sigma, $\mathrm{P}-2308)$ and $17.4 \mu \mathrm{l}$ of water. Proteinase $\mathrm{K}$ was then neutralized at $98^{\circ} \mathrm{C}$ for $10 \mathrm{~min}$ before pre-amplification.

DNA from blood of rams, ewes and lambs was extracted using standard alkaline lysis method.

\section{Primer Extension Pre-Amplification (PEP-PCR) and Sex Diagnosis on Embryo Biopsy}

Whole genome amplification by PEP-PCR was performed as previously described (Zhang et al., 1992). Briefly, to $3 \mu \mathrm{l}$ of extracted and neutralized samples was added $1.6 \mu \mathrm{l}$ of a $400 \mu \mathrm{M}$ solution of 15-base random oligonucleotides (Sigma-Aldrich, Saint Quentin Fallavier, France), $1.2 \mu \mathrm{l}$ of $25 \mathrm{mM} \mathrm{MgCl}_{2}, 0.2 \mu \mathrm{l}$ of $10 \mathrm{mM}$ dNTPs, $2 \mu \mathrm{l}$ of $10 \times$ PCR buffer, $0.3 \mu \mathrm{l}$ of Taq polymerase (Eurogentec, $5 \mathrm{U} / \mu \mathrm{l}$ ) and brought to $20 \mu \mathrm{l}$ with water. After a 4 min DNA denaturation step at $94^{\circ} \mathrm{C}, 50$ primer extension cycles were carried out in a gradient thermocycler (Mastercycler ${ }^{\circledR}$ gradient, Eppendorf, Germany). Each cycle consisted of a $1 \mathrm{~min}$ denaturation step at $94^{\circ} \mathrm{C}$, following by a 2 min annealing at $37^{\circ} \mathrm{C}$, a programmed ramping step of $0.3^{\circ} \mathrm{C} / \mathrm{sec}$ to $55^{\circ} \mathrm{C}$ and a 4 min polymerase extension step at $55^{\circ} \mathrm{C}$. Each sample was then analysed for sex diagnosis.

Duplex PCR was carried out to amplify the ZFX/ZFY gene (Zinc Finger Protein), gene common to $\mathrm{X}$ and $Y$ chromosomes, and the SRY gene (sex-determining region Y), a Y chromosome-specific sequence. Primer sequences and GenBank accession numbers of targets are given in Table 1 . Five $\mu l$ of pre-amplified sample were

TABLE 1. Primers Sequences

\begin{tabular}{|c|c|c|c|}
\hline Gene & GenBank accession no. & Primer & Sequence $\left(5^{\prime}-3^{\prime}\right)$ \\
\hline $\mathrm{ZFX} / \mathrm{ZFY}$ & AJ000269/AJ000270 & $\begin{array}{l}\text { P1-5EZ } \\
\text { P2-5EZ }\end{array}$ & $\begin{array}{l}\text { ataatcacatggagagccacaagct } \\
\text { gcacttctttggtatctgagaaagt }\end{array}$ \\
\hline SRY & Z30265 & $\begin{array}{l}\text { SRY-c-F1 } \\
\text { SRY-c-R1 }\end{array}$ & $\begin{array}{l}\text { gctgggatacgagtggaaaa } \\
\text { agctgctgtgatgctcettt }\end{array}$ \\
\hline PRNP & DQ408530 & $\begin{array}{l}\text { PrePRP-F } \\
\text { PrePRP-R } \\
\text { PRP1 } \\
\text { PRP2 } \\
\text { PRP5 } \\
\text { PRP171F } \\
\text { PRP171R } \\
\text { PRP154F } \\
\text { PRP154R } \\
\text { PRP136F } \\
\text { PRP136R } \\
\text { Probe171-R } \\
\text { Probe171-G } \\
\text { Probe171-H } \\
\text { Probe154-R } \\
\text { Probe154-H } \\
\text { Probe136-A } \\
\text { Probe136-V }\end{array}$ & $\begin{array}{l}\text { cccagtaagccaaaaaccaa } \\
\text { agcctgggattctctctggt } \\
\text { aagtgtactacagaccagttgatc } \\
\text { atgcacatttgctccaccactcgc } \\
\text { gcagctggagcagtggtaggg } \\
\text { gttaccccaaccaagtgtactacaga } \\
\text { tgttgacacagtcatgcacaaag } \\
\text { tggcaatgactatgaggaccg } \\
\text { tggtctgtagtacacttggttggg } \\
\text { gatagtaacggtcctcatagtcattgc } \\
\text { ctgcagctggagcagtggta } \\
\text { FAM-ccagtggatcggtata-Q } \\
\text { VIC-accagtggatcagtata-Q } \\
\text { VIC-accagtggatcattat-Q } \\
\text { FAM-actatcgtgaaaacat-Q } \\
\text { VIC-tactatcatgaaaacatg-Q } \\
\text { FAM-tcatggcacttcc-Q } \\
\text { VIC-ctcatgacacttcc-Q }\end{array}$ \\
\hline
\end{tabular}


added to $1.2 \mu \mathrm{l}$ of $25 \mathrm{mM} \mathrm{MgCl} 2,0.4 \mu \mathrm{l}$ of $10 \mathrm{mM}$ dNTPs, $0.4 \mu \mathrm{l}$ of each $25 \mu \mathrm{M}$ primer, $2 \mu \mathrm{l}$ of $10 \times$ PCR buffer, $0.2 \mu \mathrm{l}$ of Taq polymerase (Eurogentec, $5 \mathrm{U} / \mu \mathrm{l}$ ) and brought to $20 \mu \mathrm{l}$ with water. The PCR protocol included an initial step of $94^{\circ} \mathrm{C}$ for $4 \mathrm{~min}$, followed by 35 cycles of $94^{\circ} \mathrm{C}$ for $20 \mathrm{sec}, 60^{\circ} \mathrm{C}$ for $20 \mathrm{sec}, 72^{\circ} \mathrm{C}$ for $40 \mathrm{sec}$ and ended with a final extension at $72^{\circ} \mathrm{C}$ for $5 \mathrm{~min}$. All PCR products were visualized by ethidium-bromide-stained $2 \%$ agarose gel electrophoresis. After migration of PCR products, males have two bands at $320 \mathrm{bp}$ (SRY) and $447 \mathrm{bp}$ (ZFX/ZFY), and females only one band at $447 \mathrm{bp}$ (ZFX).

\section{Specific PrP Gene Pre-Amplification}

PCR was performed to amplify a $369 \mathrm{bp}$ region of the PrP gene of including codons 136, 154 and 171 with specific primers PrePRP-F and PrePRP-R given in Table 1. Five microlitres of extracted and neutralized samples were added to $1.2 \mu \mathrm{l}$ of $25 \mathrm{mM} \mathrm{MgCl}, 0.4 \mu \mathrm{l}$ of $10 \mathrm{mM}$ dNTPs, $0.4 \mu \mathrm{l}$ of each $25 \mu \mathrm{M}$ primer, $2 \mu \mathrm{l}$ of $10 \times$ PCR buffer, $0.2 \mu \mathrm{l}$ of Taq polymerase (Eurogentec, $5 \mathrm{U} /$ $\mu \mathrm{l})$ and brought to $20 \mu \mathrm{l}$ with water. The PCR protocol included an initial step of $94^{\circ} \mathrm{C}$ for $4 \mathrm{~min}$, followed by 36 cycles of $94^{\circ} \mathrm{C}$ for $20 \mathrm{sec}, 63^{\circ} \mathrm{C}$ for $20 \mathrm{sec}$ and $72^{\circ} \mathrm{C}$ for $40 \mathrm{sec}$ and ended with a final extension at $72^{\circ} \mathrm{C}$ for $5 \mathrm{~min}$. Product identity was confirmed with ethidium-bromide-stained $2 \%$ agarose gel electrophoresis before PrP genotyping. PCR-RFLP and TaqMan ${ }^{\mathbb{B}}$ assays were applied to determine PrP genotype of the biopsy.

\section{PrP Genotyping}

PCR-RFLP and TaqMan ${ }^{\circledR}$ assays were applied to determine PrP genotype of the biopsy, ewes, rams and lambs. Primers and probe information are given in Table 1.

PCR-RFLP genotyping was conducted as in Elsen et al. (1999), with slight modification for primer PRP5. Briefly, genotype at codon 171 was determined by the restriction profile of a PCR fragment obtained using primers PRP1 and PRP2 with BclI enzyme. Genotype at codons 136 and 154 was determined by the restriction profile of a PCR fragment obtained using primers PRP5 and PRP2 with BspHI enzyme.

TaqMan $^{\text {B }}$ genotyping assay was also used to genotype separately codons 136, 154 and 171: each codon was determined by a 5'nuclease assay with specific $\mathrm{F}$ and $\mathrm{R}$ primers for amplification, and TaqMan probes with FAM or VIC fluorochromes and Quencher coupled to allele-specific oligonucleotides, on ABI PRISM 7900 HT (Applied Biosystems, Courtaboeuf, France).

\section{Warming and Embryo Transfer Procedures}

Transfers were done at the end of the reproductive season (winter), in two different locations (CITA Zaragoza Spain and INRA Nouzilly France). After warming, embryos were transferred directly into synchronized ewes, 7 days after the onset of oestrus detected with vasectomised rams $24-48 \mathrm{hr}$ after sponge removal. Two embryos were transferred per recipient. Recipients were multiparous and dry ewes maintained indoors for 3 months before transfer. They were sedated with $0.3 \mathrm{mg} \mathrm{kg}^{-1}$ i.v. acepromazine $\left(\right.$ Calmivet $^{\circledR}$, Vetoquinol, Lure, France). After endoscopic control of the presence of at least one functional corpus luteum, embryos were transferred as follows. For warming, straws were held $5 \mathrm{sec}$ in air followed by $15 \mathrm{sec}$ in a $22^{\circ} \mathrm{C}$ water bath. After warming, the entire contents of the straw $(250 \mu \mathrm{l})$ was deposed surgically with a prototype instrument (IMV, l'Aigle-France) into the uterine horn without embryo selection nor cryoprotectant removal. For fresh whole embryos transfer, two embryos were put, just after collection, into a Tomcat linked to a $1 \mathrm{ml}$ syringe and introduced into the uterine horn of the recipient.

\section{Pregnancy Rate}

Pregnancy rate was diagnosed at Day 17 after estrus by progesterone assay (RIA method) (Saumande and Thimonier, 1972): a female was considered pregnant if progesterone concentration was higher than $1.5 \mathrm{ng} / \mathrm{ml}$. It was confirmed by ultrasound examinations on Day 42 and PAG assay (pregnancy-associated glycoprotein; RIA method) (Gonzalez et al., 1999) on Days 42 and 90, and finally by observation of lambing at term. The lambing rate was defined as the lambed/transferred recipient ratio and the embryo survival rate was defined as the lambs born/transferred embryo ratio.

\section{Parentage Control}

At birth, parentage control of each lamb was performed to assess clearly which transferred embryo had given a product. After DNA extraction from blood, genotypes were identified using a panel of 9 microsatellite markers (CSRD0247, OLADRB, INRA49, MAF214, MAF65, McM42, McM527, OarFCB20, TGLA53). Allele sizes were determined by capillary electrophoresis on ABI3100 automated sequencer (Applied Biosystems). Parentage was controlled by checking the mendelian transmission of alleles from parents to the products.

\section{Statistical Analysis}

This study was designed to compare different embryo qualities after transfer, biopsied versus control, and vitrified versus fresh. Comparisons were performed using the Chi-square test. Statistical significance was denoted as $P<0.05$.

\section{RESULTS}

\section{Embryo Collection and Biopsy}

Sixteen donors were synchronized for embryo biopsy. From 4 donors, only unfertilised oocytes or retarded embryos were recovered $(n=37)$. From the 12 other donors, 110 transferable embryos (i.e. compacted morulae and blastocysts) and 44 unfertilised or retarded embryos were recovered. Among the 110 transferable embryos, 20 were kept for control and 90 were biopsied. During embryo biopsy, one biopsy was lost and the corresponding embryo was eliminated. Among the 89 embryos, 71 were biopsied and vitrified just after in vivo collection and 18 after $24 \mathrm{hr}$ of in vitro culture. 
Among the 20 whole embryos kept for control, 16 were vitrified just after collection and 4 after culture.

\section{Sex Diagnosis and PrP Genotype Predetermination on Embryo Biopsy}

After primer extension pre-amplification (PEP-PCR) and sex diagnosis, sex genotyping of 86 embryos was clearly diagnosed (96.6\%), and 3 were thought to be female but it was uncertain. Results of PrP genotype determination are given in Table 2. Among the 89 embryo biopsies, $76 \mathrm{PrP}$ genotypes were efficiently determined (85.4\%). Ten embryo biopsies had two possible genotypes (one principal and one considered as contamination), and three had an incompatible genotype between the two techniques and remained undetermined for 2 and 4 codons out of 6 . Among 534 analysed codons, 512 were determined (95.8\%). When parent genotype was compared, 76 embryo biopsy genotypes were concordant (85.4\%) (70/76 genotyped $+5 / 10$ contaminated $+1 / 3$ not fully determined embryo biopsy), six were impossible, five had 2 possible genotypes and two remained not fully determined. Comparison with parent genotype allowed determination of 515 codons out of 534 (96.4\%).

\section{Lambing and Embryo Survival Rate}

All 89 biopsied embryos were transferred to 45 recipients (one recipient received just one embryo). Eight days after transfer, one recipient died and was excluded from the study. No significant differences were found between locations or recipient genotype (Ile de France or Rasa Aragonesa) so, the results were pooled. The rate of pregnancy obtained for biopsied and vitrified control embryos are shown in Table 3. For biopsied and vitrified control embryos, results of pregnancy were lower when embryos were cultured $24 \mathrm{hr}$ before vitrification compared to $0 \mathrm{hr}$ vitrification, but the difference was not significant and results were pooled. The pregnancy rate, evaluated at Days 17, 42, 90 was not significantly different between each group of transfer and the lambing rate was not affected by embryo biopsy and embryo vitrification, $54.5 \%, 60 \%$ and $66.6 \%$ respectively for biopsied embryos, whole vitrified embryos, and fresh whole embryos. The embryo survival rate was not significantly affected by biopsy when embryos were vitrified $(P=0.38$ ), but tended to be lower when biopsied and vitrified embryos were compared to fresh whole embryos ( $34.5 \%$ - $30 / 87$ vs. $52.6 \%$ - $20 / 38$, respectively, $P=0.057)$.

\section{Accuracy of Sex Diagnosis and PrP Genotype Determination}

Among the 30 lambs coming from biopsied, sexed and transferred embryos, $29(96.7 \%)$ had an accurate sex diagnosis. Only one male was diagnosed as a female. The recipients which received an embryo suspected to be female but uncertain were not pregnant. One lamb died 1 month before term and unfortunately no blood sample was taken, so descendant control and PrP genotype analysis were carried out on just 29 lambs. Accuracy of $\operatorname{PrP}$ genotype determination is given in Tables 2 and 4. Among the 70 determined PrP genotypes corresponding to parent genotype, 25 transferred embryos gave birth and all $25 \mathrm{PrP}$ genotype predeterminations were accurate. Among the 5 double genotypes (contaminated genotype), one embryo (B) gave birth and the right $\mathrm{PrP}$ genotype was the principal one (not the contaminant). Among both not fully determined genotypes, two lambs were born (C, D). Lamb PrP genotype was in agreement to parent $\operatorname{PrP}$ genotype and to partial embryo biopsy genotype (4 codons among 6). Finally, among 6 impossible PrP genotype determinations, one lamb was born (A): lamb PrP genotype was in agreement with parent genotype, but not with embryo biopsy genotype for 2 codons among 6. Altogether, on 174 determined codons ( $6 \times 29$ born lambs), $166(95.4 \%)$ were accurately predetermined.

\section{DISCUSSION}

In the present study, sex diagnosis and PrP genotype determination were carried out on ovine embryo microblade biopsies. Accuracy of genotype diagnosis and viability of the biopsied embryos were tested after vitrification, warming and embryo transfer into recipient. The embryo survival rate obtained with biopsied/ vitrified embryos was similar to those reported by Leoni et al. (2000) (34.5\% vs. $40 \%)$ in the same species. This rate was not significantly different to that obtained with whole vitrified embryos in the present study. Only 10.5 points were lost after embryo microblade biopsy (34.5\% for biopsied vitrified embryos versus $45 \%$ for whole vitrified embryo). A greater loss, 16\%, was reported by Hasler et al. (2002) with in vivo frozen bovine embryos and the same technique of biopsy (50\% vs. $66 \%$ ), but only $8 \%$ with fresh embryos. Quality and

TABLE 2. PrP Genotype Determination on Embryo Biopsy, Comparison With Parent Genotype and Control With Lamb Genotype After Birth

\begin{tabular}{lcc}
\hline $\begin{array}{l}\text { Embryo biopsy genotype, number } \\
\text { of determined codons }\end{array}$ & $\begin{array}{c}\text { Parents genotype comparison, number } \\
\text { of codons in agreement }\end{array}$ & $\begin{array}{c}\text { Lamb genotype control (29 births), } \\
\text { number of accurately determined codons }\end{array}$ \\
\hline 76 genotyped (85.4\%), 456/456 & $\begin{array}{c}70 \text { concordant }(78.7 \%), 420 / 420 \\
6 \text { impossible }(6.75 \%), 30 / 36\end{array}$ & $\begin{array}{c}25 \text { exact genotypes }(86.2 \%), 150 / 150 \\
1 \text { wrong (lamb A) }(3.45 \%), 4 / 6\end{array}$ \\
10 contamined (11.2\%), 46/60 & 5 concordant $(5.6 \%), 30 / 30$ & 0 \\
& 5 contamined $(5.6 \%), 23 / 30$ & 1 exact (lamb B) $(3.45 \%), 6 / 6$ \\
3 not fully determined (3.4\%), 10/18 & $\begin{array}{c}1 \text { determined and concordant }(1.1 \%), 6 / 6 \\
2 \text { not fully determined }(2.25 \%), 6 / 12\end{array}$ & 2 exact (lambs C and D) (6.9\%), 6/12 \\
\hline
\end{tabular}




\section{F. GUIGNOT ET AL.}

TABLE 3. Pregnancy Rate of In Vivo Produced Sheep Embryos, After Biopsy and Vitrification

\begin{tabular}{|c|c|c|c|c|c|c|c|c|}
\hline \multirow[b]{2}{*}{ Embryo } & \multirow[b]{2}{*}{$\begin{array}{c}\text { Time of } \\
\text { vitrification }\end{array}$} & \multirow[b]{2}{*}{$\begin{array}{c}\text { Recipient } \mathrm{n} \\
\text { (embryos) }\end{array}$} & \multicolumn{5}{|c|}{ Pregnancy rate $\%(\mathrm{n})$} & \multirow[b]{2}{*}{ Lamb sex } \\
\hline & & & Day 17 & Day 42 & Day 90 & Lambing & $\begin{array}{l}\text { Embryo } \\
\text { survival }\end{array}$ & \\
\hline \multirow[t]{3}{*}{ Biopsied vitrified } & $0 \mathrm{hr}$ & $36(71)^{*}$ & $69.4(25)$ & $61.1(22)$ & $58.3(21)$ & $58.3(21)$ & $38(27)$ & $14 \mathrm{f}, 13 \mathrm{~m}$ \\
\hline & $24 \mathrm{hr}$ & $8(16)$ & $62.5(5)$ & $37.5(3)$ & $37.5(3)$ & 35.5 (3) & $18.75(3)$ & $1 \mathrm{f}, 2 \mathrm{~m}$ \\
\hline & Total & $44(87)$ & $68.2^{\mathrm{a}}(30)$ & $56.8^{\mathrm{a}}(25)$ & $54.5^{\mathrm{a}}(24)$ & $54.5^{\mathrm{a}}(24)$ & $34.5^{\mathrm{a} \alpha}(30)$ & $15 \mathrm{f}, 15 \mathrm{~m}$ \\
\hline \multirow{3}{*}{ Control vitrified } & $0 \mathrm{hr}$ & $8(16)$ & $62.5(5)$ & $62.5(5)$ & $62.5(5)$ & $62.5(5)$ & $50(8)$ & $4 \mathrm{f}, 4 \mathrm{~m}$ \\
\hline & $24 \mathrm{hr}$ & $2(4)$ & $100(2)$ & 50 (1) & 50 (1) & $50(1)$ & $25(1)$ & $1 \mathrm{~m}$ \\
\hline & Total & $10(20)$ & $70^{\mathrm{a}}(7)$ & $60^{\mathrm{a}}(6)$ & $60^{\mathrm{a}}(6)$ & $60^{\mathrm{a}}(6)$ & $45^{\mathrm{a} \alpha \beta}(9)$ & $4 \mathrm{f}, 5 \mathrm{~m}$ \\
\hline Fresh & & $21 * *(38)$ & $85.7^{\mathrm{a}}(18)$ & $66.6^{\mathrm{a}}(14)$ & $66.6^{\mathrm{a}}(14)$ & $66.6^{\mathrm{a}}(14)$ & $52.6^{\mathrm{a} \beta}(20)$ & $8 \mathrm{f}, 12 \mathrm{~m}$ \\
\hline
\end{tabular}

f: female; m: male.

a, b values differ significantly ( $P<0.05$ chi-square test).

$\alpha, \beta$ tendency $(P=0.057$ chi-square test).

*One recipient had received just one embryo.

**Four recipients had received just one embryo.

development stage of the embryos have a real effect on the embryo viability after microblade biopsy, especially after cryopreservation. Peippo et al. (2007) have obtained the highest number of excellent quality Day 8 embryos for transfer with advanced developmental stages and embryo of quality code 1 after bovine embryo microblade biopsy. Biopsy size could be reduced and then embryo viability enhanced. The good result of embryo survival obtained in the present study with blastocysts and expanded blastocysts demonstrated that microblade biopsy technique could be a field method of choice for ovine blastocysts, with poor embryo damage even if a few cells are destroyed around the cutting edge and the surrounding zona pellucida is frequently completely removed with this technique compared to cell aspiration.

Embryo survival rates obtained with fresh and vitrified control embryos observed in this study were not significantly different $(52.6 \%$ and $45 \%$, respectively). These results were similar to those found by Alabart et al. (2007) with fresh embryos (55.8\%), but they are somewhat lower than those reported previously by Baril et al. (2001) (60\% and 50\% with fresh and vitrified embryos, respectively), Leoni et al. (2000) and Dattena et al. (2004) $68.7 \%$ and $63 \%$, respectively, with vitrified embryo). This difference could be attributed to batches and breeds of recipient females, vitrification technique or age of donors and season of embryo production that may affect embryo quality.

After PEP-PCR and sex diagnosis, percentages of correct sex diagnosis obtained in the present study are very high: $96.6 \%$ of samples were efficiently diagnosed, and $96.7 \%$ of born lamb sex was accurately diagnosed. These results are similar to those of Hochman et al. (1996), Chrenek et al. (2001) and Tominaga and Hamada (2004) with the same method of genome preamplification in bovine $(97 \%, 91 \%$ and $89 \%$, respectively) and to those of Mara et al. (2004) with ovine biopsied embryos, but without pre-amplification (100\% efficiency and $87 \%$ accuracy). In the present study, one male was diagnosed female. Even without whole genome pre-amplification, it is the common mistake. However, as ZFY/ZFX gene was used as an autosomal control, a specific restriction endonuclease could be applied on top of this to totally ensure the correct sex of ovine embryo biopsy (Bredbacka and Peippo, 1992; Bernardi et al., 1996). Despite this mistake, the present study reported for the first time a sex diagnosis method on embryo biopsy coupled with whole pre-amplification genome giving very encouraging success rates in sheep, without increasing contamination risk due to several steps required. Moreover, it generated a lot of copy of the whole genome, which allowed different multiplex genotyping on the same sample. However, as nested PCR was noticed to be more efficient and accurate that PEP-PCR for PrP during preliminary tests, nested PCR was chosen instead of PEP-PCR to test for the first time PrP genotype predetermination on ovine embryo biopsy.

After nested PCR, the percentage of predetermined $\operatorname{PrP}$ genotype from 89 embryo biopsies was acceptable; $85.4 \%$ of biopsies could be completely predetermined and $95.8 \%$ of codons were predetermined. The accuracy

TABLE 4. PrP Genotype of Lambs A, B, C and D, Their Parents and Corresponding Embryo Biopsies

\begin{tabular}{|c|c|c|c|}
\hline Lambs & Lamb genotype & Parent genotype & Embryo biopsy genotype \\
\hline $\mathrm{A}$ & $\mathrm{AHQ} / \mathrm{VRQ}$ & ARR/VRQ, AHQ/ARQ & VRQ/VRQ \\
\hline B & ARQ/AHQ & ARR/ARQ, AHQ/ARQ & $\underline{\mathrm{ARQ}} / \underline{\mathrm{AHQ}}$, contamined by $\underline{\mathrm{ARR}} / \underline{\mathrm{ARQ}}$ \\
\hline C & ARR/ARR & ARR/VRQ, ARR/ARR & 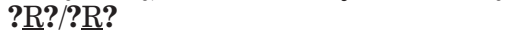 \\
\hline $\mathrm{D}$ & $\mathrm{ARQ} / \mathrm{AHQ}$ & ARR/ARQ, AHQ/ARQ & $\underline{\underline{\mathrm{AR}}} ? / \underline{\underline{\mathrm{AH}}} ?$ \\
\hline
\end{tabular}

Underlined codons of embryo biopsies genotype are in agreement with parent genotype. Codons written in bold are wrong predetermined or undetermined. 
of PrP genotyping was high too (95.4\%). These results are in agreement with those of Virta et al. (2002) and Peippo et al. (2007) in bovine embryos with the same preamplification method (nested PCR), but with another target gene region (ZFX/ZFY and milk production markers), 96-99\% of accuracy. Few incorrect determinations of PrP genotypes are probably the consequence of preferential amplification of one allele, or limited efficiency of PCR on very small samples.

It is obvious that genotyping or sex determination may have imperfect efficiency or reliability when the amount of DNA is very limited. The performance in the present study was comparable with other similar studies performed using very small DNA samples. All these studies working on low quantities of DNA share basically the same process: a first step of genome or target amplification, and a second step of genotyping. Both steps have specific risks. PEP-PCR may lead to incomplete genome coverage (portions of the genome can be lost), and produce usually small fragments of DNA (at each cycle, degenerate primers bind internally to previous products). New whole genome amplification procedures, as multiple displacement amplification (MDA, a non PCR-based method), can provide a greater yield of DNA from tiny samples, with longer fragments, and could be less prone to allele dropout (Dean et al., 2002; Hellani et al., 2004; Sun et al., 2005; Peng et al., 2007). To take into account the relatively small size of DNA fragments produced by genome amplification (PEP-PCR or MDA), it is possible to make smaller PCR that could be more efficient for sex determination or genotyping using specifically designed primers. For $\operatorname{PrP}$ genotyping, two different techniques were used in the present study: PCR/RFLP and TaqMan ${ }^{\mathbb{R}}$ assays, and only 3 samples out of 89 gave partially conflicting results between these two techniques. Usually, TaqMan ${ }^{\mathbb{B}}$ genotypes had very high confidence score because it is more sensitive than PCR/RFLP, but both techniques can be affected by bias in genome amplification, and particularly allele dropout. It is difficult to circumvent allele dropout in such cases. To increase the confidence level in the genotypes, it is possible to replicate genome amplification and genotyping on different aliquots of DNA extracts (multiple tubes approach, as in Taberlet et al., 1996).

Even if more studies are needed to try to reach similar results with PEP-PCR or other techniques of whole genome amplification as with nested PCR, these totally original results on ovine scrapie predetermination from embryo biopsy, followed by embryo cryopreservation, are very encouraging. It will increase the efficiency and reduce the cost of selection process aiming to eradicate alleles of scrapie sensitivity in the ovine population.

\section{CONCLUSIONS}

DNA pre-amplification, PEP-PCR and nested PCR are very accurate for sex diagnosis and $\operatorname{PrP}$ genotype predetermination, respectively, from ovine embryo microblade biopsy. Post transfer viability of in vivo biopsied embryos after vitrification/warming tended to be slightly reduced compared to intact vitrified or fresh embryos. These original results allowed selection at the same time genotypes resistant to scrapie and sex of offspring before transfer of cryopreserved embryos. Moreover, other target genes linked to other diseases or to production traits could be analysed on the same biopsy sample thanks to PEP-PCR conferring an increased economical value to the embryo obtained by multiple ovulation embryo transfer (MOET).

\section{ACKNOWLEDGMENTS}

The authors are grateful to L. Ouvrard and his team at INRA Nouzilly for ewe embryo production and for their care to the animals during pregnancy. They wish to thank sincerely J. Cognié and her team for their help during embryo transfer, J.L. Touzé for the ultrasound examinations, S. Pennetier and R. Dalbies-Tran for skilful help in PCR technique. They thank P. Lonergan for English revision of the manuscript.

\section{REFERENCES}

Aasen E, Medrano JF. 1990. Amplification of the ZFY and ZFX genes for sex identification in human, cattle, sheep and goats. Biotechnology 8:1279-1281.

Alabart JL, Dervishi E, Cocero MJ, Sanchez P, Echegoyen E, MartinezRoyo A, Calvo JH, Folch J. 2007. Sexing of ovine embryos within a moet selection program. Proc 23th annual meet AETE Alghero, p. 122 .

Andréoletti O, Lacroux C, Chabert A, Monnereau L, Tabouret G, Lantier F, Berthon P, Eychenne F, Lafond-Benestad S, Elsen JM, Schelcher F. 2002. PrP $\mathrm{P}^{\mathrm{Sc}}$ accumulation in placentas of ewes exposed to natural scrapie: Influence of foetal PrP genotype and effect on eweto-lamb transmission. J Gen Virol 83:2607-2616.

Appa Rao KBC, Totey SM. 1999. Cloning and sequencing of buffalo male, specific repetitive DNA: Sexing of in Vitro developed buffalo embryos using multiplex and nested polymerase chain reaction. Theriogenology 51:785-797.

Baril G, Traldi AL, Cognie Y, Leboeuf B, Beckers JF, Mermillod P. 2001. Successful direct transfer of vitrified sheep embryos. Theriogenology 56:299-305.

Bernardi ML, Delouis C. 1996. Sex-related differences in the developmental of in vitro matured/in vitro fertilized ovine embryos. Hum Reprod 11:621-626.

Bernardi ML, Cotinot C, Payen E, Delouis C. 1996. Transcription of Yand $\mathrm{X}$-linked genes in preimplantation ovine embryos. Mol Reprod Dev 45:132-138.

Bolton DC, McKinley MP, Prusiner SB. 1982. Identification of a protein that purifies with the scrapie prion. Science 218:1309-1311.

Bredbacka P. 2001. Progress on methods of gene detection in preimplantation embryos. Theriogenology 55:23-34.

Bredbacka P, Peippo J. 1992. Sex diagnosis of ovine and bovine embryos by enzymatic amplification and digestion of the DNA from the ZFY/ ZFX locus. Agric Sci Fin 2:233-238.

Bredbacka P, Kankaanpää A, Peippo J. 1995. PCR-sexing of bovine embryos: A simplified protocol. Theriogenology 44:167-176.

Chrenek P, Boulanger L, Heyman Y, Uhrin P, Laurincik J, Bulla J, Renard JP. 2001. Sexing and multiple genotype analysis from a single cell of bovine embryo. Theriogenology 55:10711081.

Dattena M, Accardo C, Pilichi S, Isachenko V, Mara L, Chessa B, Cappai P. 2004. Comparison of different vitrification protocols on viability after transfer of ovine blastocystes in vitro produced and in vivo derived. Theriogenology 62:481-493.

Dean FB, Hosono S, Fang L, Wu X, Farugi F, Bray-Ward P, Sun Z, Zong O, Du Y, Du J, Driscoll M, Song W, Kingsmore S, Egholm M, Lasken RS. 2002. Comprehensive human genome amplification using multiple displacement amplification. Proc Natl Acad Sci USA 99: 5261-5266 


\section{F. GUIGNOT ET AL.}

Diaz C, Vitezica ZG, Rupp R, Andreoletti O, Elsen JM. 2005. Polygenic variation and transmission factors involved in the resistancesusceptibility to scrapie in a Romanov flock. J Gen Virol 86:849-857.

Dickinson AG. 1976. Scrapie in sheep and goats. In: Kimberlin RH, editor. Slow virus diseases of animals and man. North-Holland: Amsterdam. pp. 209-241.

Elsen JM, Amigues Y, Schelcher F, Ducrocq V, Andreoletti O, Eychenne F, Tien Khang JV, Poivey JP, Lantier F, Laplanche JL. 1999. Genetic susceptibility and transmission factors in scrapie: Detailed analysis of an epidemic in a closed flock of Romanov. Arch Virol 144:431-445.

Georges M. 2001. Recent progress in livestock genomics and potential impaction breeding programs. Theriogenology 55:15-21.

Goldmann W, Baylis M, Chihota C, Stevenson E, Hunter N. 2005. Frequencies of PrP gene haplotypes in British sheep flocks and the implications for breeding programmes. J Appl Microbiol 98:12941302.

Gonzalez F, Sulon J, Garbayo JM, Batista M, Cabrera F, Calero P, Gracia A, Beckers JF. 1999. Pregnancy-associated glycoprotein concentrations in plasma samples. Theriogenology 52:717-725.

Guignot F, Bouttier A, Baril G, Salvetti P, Pignon P, Beckers JF, Touzé JL, Cognie J, Traldi AS, Cognié Y, Mermillod P. 2006. Improved vitrification method allowing direct transfer of goat embryos. Theriogenology 66:1004-1101.

Hasler JF, Cardey E, Stokes JE, Bredbacka P. 2002. Nonelectrophoretic PCR-sexing of bovine embryos in a commercial environment. Theriogenology 58:1457-1469.

Hellani A, Coskun S, Benkhalifa M, Tbakhi A, Sakati N, Al-Odaib A, Ozand P. 2004. Multiple displacement amplification on single cell and possible PGD applications. Mol Hum Reprod 10:847-852.

Hirayama H, Kageyama S, Moriyasu S, Sawai K, Onoe S, Takahashi Y, Katagiri S, Toen K, Watanabe K, Notomi T, Yamashina H, Matsuzaki S, Minamihashi A. 2004. Rapid sexing of bovine preimplantation embryos using loop-mediated isothermal amplification. Theriogenology 62:887-896.

Hochman D, Zaron Y, Dekel I, Feldmesser E, Medrano JF, Shani M, Ron M. 1996. Multiple genotype analysis and sexing of IVF bovine embryos. Theriogenology 46:1063-1075.

Holm P, Booth PJ, Schmidt MH, Greve T, Callesen H. 1999. High bovine blastocyst development in a static in vitro production system using SOFaa medium supplemented with sodium citrate and myoinositol with or without serum-proteins. Therio 52:683-700.

Hunter N. 1997. PrP genetics in sheep and the applications for scrapie and BSE. Trends Microbiol 5:331-334.

Hunter N, Foster JD, Goldmann W, Stear MJ, Hope J, Bostock C. 1996. Natural scrapie in a closed flock of Cheviot sheep occurs only in specific PrP genotypes. Arch Virol 141:809-824.

Kochhar HS, Buckrell BC, Pollard JW, King WA. 2000. Production of sexed lambs after biopsy of ovine blastocyst produced in vitro. Can Vet J 41:398-400.

Lacaze S, Lesclaux J, Coupet H. 1996. The sexing of bovine embryos in the south-west of France. Part 1. Efficiency, accuracy and pregnancy after 3 years activity. Proc 12th annual meet AETE Lyon, p. 156.

Lacaze S, Ponsart C, Humblot P. 2007. Sexing and direct transfer of bovine biopsied frozen-thawed embryos under on-farm conditions in a commercial program. Proc 23th annual meet AETE Alghero, p. 188.

Leoni G, Ledda S, Bogliolo L, Naitana S. 2000. Novel approach to cell sampling from preimplantation ovine embryos and its potential use in embryonic genome analysis. J Reprod Fertil 119:309-314.

Lien S, Cockett NE, Klungland H, Arnheim N, Georges M, Gomez-Raya L. 1999. High-resolution gametic map of the sheep callipyge region: Linkage heterogeneity among rams detected by sperm typing. Anim Genet 30:42-46.
Lopes RFF, Forez F, Oliveira ATD, Rodrigues JL. 2001. Splitting and biopsy for bovine embryo sexing under field conditions. Theriogenology 56:1383-1392.

Manna L, Neglia G, Marino M, Gasparrini B, Di Palo R, Zicarelli L. 2003. Sex determination of buffalo embryos (Bubalus bubalis) by polymerase chain reaction. Zygote 11:17-22.

Mara L, Pilichi S, Sanna A, Accardo C, Chessa B, Chessa F, Dattena M, Bomboi G, Cappai P. 2004. Sexing of in vitro produced ovine embryos by duplex PCR. Mol Reprod Dev 69:35-42.

Mermillod P, Traldi AL, Baril G, Beckers JF, Massip A, Cognié Y. 1997. A vitrification method for direct transfer of sheep embryos. In: Proc 15th annual meet AETE 212.

Notomi T, Okayama H, Masubuchi H, Yonekawa T, Watanabe K, Amino N, Hase T. 2000. Loop-mediated isothermal amplification of DNA. Nucleic Acids Res 28:e63.

Pan KM, Baldwin M, Nguyen J, Gasset M, Serban A, Groth D, Mehlhorn I, Huang Z, Fletterick RJ, Cohen FE. 1993. Conversion of $\alpha$-helices into $\beta$-sheets features in the formation of the scrapie prion proteins. Proc Natl Acad Sci USA 90:10962-10966.

Peippo J, Viitala S, Virta J, Raty M, Tammiranta N, Lamminen T, Aro J, Myllymäki H, Vilkki J. 2007. Birth of correctly genotyped calves after multiplex marker detection from bovine embryo microblade biopsies. Mol Reprod Dev 74:1373-1378.

Peng W, Takabayashi H, Ikawa K. 2007. Whole genome amplification from single cells in preimplantation genetic diagnosis and prenatal diagnosis. Eur J Obst Gynecol Reprod Biol 131:13-20.

Peura T, Hyttinen JM, Turunen M, Jänne J. 1991. A reliable sex determination assay for bovine preimplantation embryos using the polymerase chain reaction. Theriogenology 35:547-555.

Prusiner SB. 1982. Novel proteinaceous infectious particles cause scrapie. Science 216:136-144.

Saumande J, Thimonier J. 1972. Use of an early test for pregnancy by determining progesterone in peripheral blood of the ewe. Ann Biol Anim Bioch Biophys 12:661-665.

Sermon K, Lissens W, Joris H, Van Steirteghem A, Liebaers I. 1996. Adaptation of the primer extension pre-amplification (PEP) reaction for pre-implantation diagnosis: Single blastomere analysis using short PEP protocols. Mol Hum Reprod 2:209-212.

Sun G, Kaushal R, Pal P, Wolujewicz M, Smelser D, Cheng H, Lu M, Chakraborty R, Jin L, Deka R. 2005. Whole-genome amplification Relative efficiencies of the current methods. Legal Med 7:279-286.

Taberlet P, Griffin S, Goossens B, Questiau S, Manceau V, Escaravage N, Waits LP, Bouvet J. 1996. Reliable genotyping of samples with very low DNA quantities using PCR. Nucleic Acids Res 24:31893194.

Thibier M, Nibart M. 1995. The sexing of bovine embryos in the field Theriogenology 43:71-80.

Tominaga K, Hamada Y. 2004. Efficient production of sex-identified and cryosurvived bovine in-vitro produced blastocysts. Theriogenology 61:1181-1191.

Virta J, Markola J, Peippo J, Markkula M, Vilkki J. 2002. Sex determination of bovine embryo blastomeres by fluorogenic probes. Theriogenology 57:2229-2236.

Wang S, Cockett NE, Miller JM, Shay TL, Maciulis A, Sutton DL, Foote WC, Holyoak GR, Evans RC, Bunch TD, Beever JE, Call JW, Taylor WD, Marshall MR. 2002. Polymorphic distribution of the ovine prion protein $(\mathrm{PrP})$ gene in scrapie-infected sheep flocks in which embryo transfer was used to circumvent the transmissions of scrapie. Theriogenology 57:1865-1875.

Xu K, Tang Y, Grifo JA, Rosenwaks Z, Cohen J. 1993. Primer extension pre-amplification for detection of multiple genetic loci from single human blastomeres. Hum Reprod 8:2206-2210.

Zhang L, Cui X, Schmitt K, Hubert R, Navidi W. 1992. Whole genome amplification from a single cell: Implications for genetic analysis. Proc Natl Acad Sci USA 89:5847-5851. 